\title{
Application of edible nanolaminate coatings with antimicrobial extract of Flourensia cernua to extend the shelf-life of tomato (Solanum lycopersicum L.) fruit
}

\author{
Esperanza de Jesús Salas-Méndez ${ }^{\mathrm{a}}$, Antonio Vicente ${ }^{\mathrm{b}}$, Ana Cristina Pinheiro ${ }^{\mathrm{b}}$, \\ Lina Fernanda Ballesteros ${ }^{\mathrm{b}}$, Pedro Silva ${ }^{\mathrm{b}}$, Raúl Rodríguez-García ${ }^{\mathrm{a}}$, \\ Francisco Daniel Hernández-Castillo ${ }^{a}$, María de Lourdes Virginia Díaz-Jiménez ${ }^{c}$, \\ María Liliana Flores-López ${ }^{a}$, José Ángel Villarreal-Quintanilla ${ }^{a}$, Fidel Maximiano Peña-Ramos ${ }^{a}$, \\ Dennise Anahí Carrillo-Lomelía, Diana Jasso de Rodríguez ${ }^{\mathrm{a}, *}$ \\ ${ }^{a}$ Universidad Autónoma Agraria Antonio Narro, CP 25315, Saltillo, Coahuila, Mexico \\ ${ }^{\mathrm{b}}$ IBB-Institute for Biotechnology and Bioengineering, Centre of Biological Engineering, Universidade do Minho, Campus de Gualtar, Braga, Portugal \\ ${ }^{\mathrm{c}}$ Cinvestav-Saltillo, Av. Industria Metalúrgica 1062, CP 25900, Ramos Arizpe, Coahuila, Mexico
}

\section{A R T I C L E I N F O}

\section{Keywords:}

Flourensia cernua

Nanolaminate coatings

Shelf-life

Chitosan

Alginate

Tomato

\begin{abstract}
A B S T R A C T
Edible coatings have potential to reduce postharvest losses of fruit such as tomato. In this study, the effects of nanolaminate coatings incorporated with extracts of Flourensia cernua, an endemic plant of the arid and semiarid regions of Mexico, has been investigated. Ethanol extracts of $F$. cernua (FcE) were prepared and incorporated into polyelectrolyte solutions of alginate and chitosan. The nanolaminates were characterized by determining the zeta potential, contact angle and water vapor and oxygen permeabilities. Shelf-life analyses $\left(20^{\circ} \mathrm{C}\right.$ for $\left.15 \mathrm{~d}\right)$ were carried out with uncoated fruit (UCF), nanolaminate coating (NL) and nanolaminate coating with FcE $(\mathrm{NL}+\mathrm{FcE})$. Physicochemical analyses, gas exchange rates of $\mathrm{O}_{2}$ and $\mathrm{CO}_{2}$ and ethylene production, as well as microbiological analyses of treated fruit were measured. Zeta potential and contact angle measurements confirmed the successful assembly of successive nanolayers of alginate and chitosan, as well as those with $F$. cernua. The nanolaminate coatings resulted in decreased permeabilities to water and $\mathrm{O}_{2}$. The best treatment of $\mathrm{NL}+\mathrm{FcE}$, extended the shelf-life of fruit by reducing weight loss and microbial growth, reducing gas exchange and ethylene production, and maintaining firmness and color. The NL + FcE treatment are an alternative to extend the shelf-life of tomato fruit.
\end{abstract}

\section{Introduction}

Tomato (Solanum lycopersicum L.) fruit are subject to large postharvest losses due to physical and biological factors. It is a climacteric fruit, ripening being associated with increased respiration and ethylene production rates. Transpiration also affects quality as the mass transfer process that occurs during transpiration, in which the water vapor moves from the product to the environment, results in weight loss of the fruit (Hung et al., 2011; Flores-López et al., 2016a). The colonization of several microorganisms, mainly by fungi (e.g. Botrytis cinerea and Fusarium oxysporum) in the fruit can cause additional losses (RamosGarcía et al., 2012). As consequence of these factors, the shelf-life of tomato and of its market value decreases over time (Flores-López et al.,

\section{6b).}

To combat these problems, different techniques have been studied and implemented to extend the shelf-life of horticultural products (Liplap et al., 2013). Currently, it has been reported that the application of edible coatings can extend the shelf-life of fresh products (Cerqueira et al., 2011). This type of coatings improves the transport properties, suggesting that these materials can present enhanced functionalities when used at nanoscale (Jang et al., 2008). These nanocoatings can provide potential applications for food preservation, as they are made by a sequential adsorption of polyelectrolytes charged oppositely on a solid carrier, such as polyethylene terephthalate (PET) (Carneiro-daCunha et al., 2010). One of the best options to make the nanolaminate coatings is based on the layer-by-layer (LbL) assembly technique, which

\footnotetext{
* Corresponding author.

E-mail address: dianajassocantu@yahoo.com.mx (D. Jasso de Rodríguez).
} 
consists in cover charged surfaces with the deposition of multiple nanolaminate films from 1 to $100 \mathrm{~nm}$ thickness, from different materials (Fabra et al., 2016). To enhance the efficiency and stability of edible nanolaminate coatings, suitable materials must be used (Vieira et al., 2016). The application of alginate, a natural anionic polysaccharide, as an edible coating component increased the shelf life of fresh-cut fruit (Valero et al., 2013). Chitosan, a natural cationic polysaccharide, also has been of great interest due to its transport and mechanical properties (Souza et al., 2009).

Nanolaminate coatings can also incorporate functional materials, such as plant extracts that can provide a variety of biological activities (e.g. antioxidant and antimicrobial) (Flores-López et al., 2016a). Flourensia cernua is an endemic plant of the arid and semi-arid regions of Mexico, and it has been widely studied for its interesting properties. Ethanol extracts of $F$. cernua have antifungal activity as well as antioxidant capacity (Jasso de Rodríguez et al., 2007, 2017). However, there are no reports about the application of $F$. cernua extract as an incorporated functional material in the elaboration of edible nanolaminate coatings. Thus, the aims of this study were: to develop antimicrobial edible nanolaminate coatings, incorporating $F$. cernua extract, and to evaluate its effects on tomato ripening.

\section{Materials and methods}

\subsection{Materials}

Films of polyethylene terephthalate (PET; Canson, France); sodium alginate (Manutex RSX; Kelco International, Ltd., Portugal); chitosan (91.23\% deacetylation degree and high molecular weight), purchased from Golden-Shell Biochemical Co., Ltd (China); lactic acid with $90 \%$ of purity (Merck, Germany); Tween 80 (Acros Organics, Belgium); sodium hydroxide (Riedel-de Haën, Germany); and 1,6-hexanediamine (> 98\% of purity, from Sigma-Aldrich, Germany), were used to prepare the nanolaminate coatings. Dichloran-rose bengal-chloramphenicol (DRBC), glycerol and sodium chloride were supplied by Panreac (Spain); plate count agar (PCA) and peptone bacteriological, used for the microbiological assays, were purchased from HiMedia Laboratories (India). Ethanol (Sigma, St. Louis, MO, USA) was used for the extract preparation.

Tomatoes were purchased from a local supermarket in Braga, Portugal. The fruit were visually selected in a ripeness degree with a light-red color, based on the scale reported by Batu (2004). Besides, the uniformity in size, color, and absence of fungal infection were considered. Before treatment, the fruit were washed with a solution of sodium hypochlorite $(0.05 \%)$ for $3 \mathrm{~min}$ and air-dried at room temperature.

The samples of branches with leaves of $F$. cernua were collected at Southeast of Coahuila, Mexico as reported by Jasso de Rodríguez et al. (2017).

\subsection{F. Cernua extract preparation}

To obtain the $F$. cernua leaves extract, the methodology reported by Jasso de Rodríguez et al. (2017) was followed, using ethanol as solvent. The extract was preserved in a desiccator at $25^{\circ} \mathrm{C}$ and $0 \%$ relative humidity (RH), until its use.

\subsection{Aminolysis of polyethylene terephthalate surface (PET)}

Rectangular pieces of $0.8 \times 5.0 \mathrm{~cm}$ and circular pieces of $5.0 \mathrm{~cm}$ of diameter of PET films were cut. Afterwards, the pieces were aminolyzed according to the technique reported by Fu et al. (2005). Briefly, PET films were cleaned by submerging them for $3 \mathrm{~h}$ in a solution of ethanol/ water $(1: 1, v / v)$, followed by a full rinsing with distilled water. The films were then dried at $30^{\circ} \mathrm{C}$ for $24 \mathrm{~h}$. Subsequently, the films were immersed into $0.06 \mathrm{~g} \mathrm{~mL}^{-1}$ of 1,6-hexanediamine/propanol solution and left to repose at $37^{\circ} \mathrm{C}$ for $4 \mathrm{~h}$ in order to obtain the aminolyzed films. After incubation, films were completely rinsed with distilled water to remove the 1,6 -hexanediamine and then dried at $37^{\circ} \mathrm{C}$ for $24 \mathrm{~h}$. Once the aminolyzed PET films were obtained, these were treated with $0.1 \mathrm{~mol} \mathrm{~L}^{-1}$ of hydrochloric acid $(\mathrm{HCl})$ solution during $3 \mathrm{~h}$ at $20^{\circ} \mathrm{C}$ and washed with distilled water. Finally, the films were dried at $30^{\circ} \mathrm{C}$ for $24 \mathrm{~h}$ and designated as "aminolyzed/charged PET" (A/C PET). This procedure was carried out to positively charge the PET surface, with the objective of having a stronger interaction with the alginate (negatively charged).

\subsection{Preparation of polyelectrolyte solutions}

For preparing the polyelectrolyte solutions of alginate (Alg) and chitosan (Chi), the methodology reported by Fabra et al. (2016) was followed. Briefly, the Alg solution was prepared mixing $0.2 \%(\mathrm{w} / \mathrm{v})$ sodium alginate in distilled water, and for Chi solution, Chi $(0.6 \%, \mathrm{w} / \mathrm{v})$ was dispersed in an aqueous solution of lactic acid $(1.0 \%, \mathrm{v} / \mathrm{v})$. The solutions were mixed under magnetic stirring (Ika, Wilmington, USA), at room temperature, at $200 \mathrm{rpm}$ for $3 \mathrm{~h} \mathrm{(Alg)} \mathrm{and} 10 \mathrm{~h}$ (Chi), until they were completely dissolved. Glycerol was used as plasticizer at $0.05 \%$ $(\mathrm{w} / \mathrm{v})$ and $0.1 \%(\mathrm{w} / \mathrm{v})$ for $\mathrm{Alg}$ and Chi solutions, respectively; and Tween 80 was used as surfactant, at $0.05 \%(w / v)$ for $\mathrm{Alg}$, and $0.1 \%(\mathrm{w} /$ v) for Chi. The $\mathrm{pH}$ of $\mathrm{Alg}$ and Chi solutions were adjusted to $\mathrm{pH} 7.0$ with sodium hydroxide $\left(1 \mathrm{~mol} \mathrm{~L}^{-1}\right)$ and to $\mathrm{pH} 3.0$ with lactic acid $(1 \mathrm{~mol}$ $\mathrm{L}^{-1}$ ), respectively.

Afterwards, a concentration of $5000 \mathrm{mg} \mathrm{L}^{-1}$ of $F$. cernua extract (FCE), as antioxidant and antimicrobial agent, was added to each solution reaching final concentrations of $0.2 \%(\mathrm{w} / \mathrm{v})$ for Alg solution with $\mathrm{FcE}(\mathrm{Alg}+\mathrm{FcE})$ and $0.6 \%(\mathrm{w} / \mathrm{v})$ for Chi solution with FcE $(\mathrm{Chi}+\mathrm{FcE})$. Finally, the solutions were mixed for $3 \mathrm{~h}$ at room temperature to ensure homogenization.

\subsection{Preparation of edible nanolaminate coatings}

The nanolaminate coatings were built by alternate deposition of five nanolayers, to obtain two different types of nanolaminate coatings, with the following sequences: Alg-Chi-Alg-Chi-Alg (NL), and $\mathrm{Alg}+\mathrm{FcE}-\mathrm{Chi}+\mathrm{FcE}-\mathrm{Alg}+\mathrm{FcE}-\mathrm{Chi}+\mathrm{FcE}-\mathrm{Alg}+\mathrm{FcE}(\mathrm{NL}+\mathrm{FcE})$.

To prepare the nanolaminate coatings, the technique reported by Medeiros et al. (2014) was followed. First, a piece of A/C PET support was dipped into a solution of Alg or Alg + FcE during $20 \mathrm{~min}$, then the films were rinsed with deionized water with $\mathrm{pH} 7.0$ and the samples were dried by hanging them for $15 \mathrm{~min}$, inside a chamber with a nitrogen flow, to accelerate the drying process. Subsequently, the films were submerged into a solution of Chi or Chi + FcE, also during $20 \mathrm{~min}$, and then rinsed with an aqueous solution (deionized water and lactic acid) at $\mathrm{pH}$ 3.0. The films were dried following the procedure mentioned above. These procedures were repeated to obtain an alternate deposition of a total of five nanolayers, according to the sequence established above. The nanolaminate coatings obtained on A/C PET films were maintained in a desiccator at $20 \pm 2{ }^{\circ} \mathrm{C}$ and $50 \pm 5 \%$ RH.

\subsection{Edible nanolaminate coatings characterization}

\subsubsection{Zeta potential}

The zeta potential ( $\zeta$-potential) of each polyelectrolyte solution was determined by dynamic light scattering (DLS) (Zetasizer Nano ZS-90, Malvern Instruments, UK), to confirm their opposite charge. The samples were analyzed in a folded capillary cell (DTS 1060, Malvern Instruments) for the measurements at room temperature (Silva et al., 2015). Also, the effect of FcE addition on the coating solutions was evaluated. Three replicates with three readings each one, were carried out. 


\subsubsection{Contact angle measurements}

The contact angles $(\theta)$ of the surfaces of original PET, A/C PET and the subsequent nanolaminate coatings were measured by the sessile drop method, as described by Kwok and Neumann (1999), and observed with a contact angle meter (OCA 20, Dataphysics, Germany), equipped with an image analysis software. Briefly, a drop of $2 \mu \mathrm{L}$ of ultra-pure water was placed on the original PET, A/C PET and the nanolaminate coatings surfaces using a $500 \mu \mathrm{L}$ syringe (Hamilton, Switzerland) with a $0.75 \mathrm{~mm}$ diameter needle. The contact angle at each surface was measured at $15 \mathrm{~s}$, with a computer assisted image processor using a digital camera. Fifteen replicates of contact angle measurements were carried out at $20.5 \pm 0.3{ }^{\circ} \mathrm{C}$ for each formulation.

\subsubsection{Water vapor permeability (WVP)}

The WVP of the nanolaminate films was determined using the ASTM E96-92 method, with some modifications (Vieira et al., 2016). The films were sealed on the top of a permeation cells containing $50 \mathrm{~mL}$ of distilled water, each cell, in order to generate $100 \% \mathrm{RH}$ (2337 Pa vapor pressure at $20^{\circ} \mathrm{C}$ ). Subsequently, the cells were weighed using an analytical balance (Mettler AE200, Marshall Scientific, USA), and then placed into a desiccator containing previously dried silica $\left(105^{\circ} \mathrm{C}\right.$ overnight), at constant temperature of $20^{\circ} \mathrm{C}$, with $0 \% \mathrm{RH}$ and $0 \mathrm{~Pa}$ water vapor pressure, which were maintained keeping constant air circulation by installing a fan inside the desiccator. The tests were carried out by triplicate and the cells weight was measured every $2 \mathrm{~h}$ during $10 \mathrm{~h}$. The WVP of the films were showed as $\mathrm{g} \mathrm{m}^{-1} \mathrm{~s}^{-1} \mathrm{~Pa}^{-1}$, and determined by the following equation (Cooksey et al., 1999):

$\mathrm{WVP}_{\mathrm{b}}=\frac{\mathrm{L}_{\mathrm{b}}}{\left(\frac{\mathrm{L}_{\mathrm{t}}}{\mathrm{WVP}_{\mathrm{t}}}\right)-\left(\frac{\mathrm{L}_{\mathrm{a}}}{\mathrm{WVP}_{\mathrm{a}}}\right)}$

where $\mathrm{a}, \mathrm{b}$, and t correspond to A/C PET support, nanolayers and to the resulting A/C PET support coated with nanolayers, respectively, and L is the thickness of the films in millimeters (mm). The thickness of the A/ C PET film, with and without the nanolayers, was measured with a digital micrometer (No. 293-5, Mitutoyo, Japan). The thickness of each nanolaminate coating was obtained by subtracting the A/C PET film value from the A/C PET film with the nanolayers, and the proper calculations were made to obtain the values in the desired scale.

\subsubsection{Oxygen permeability $\left(\mathrm{O}_{2} \mathrm{P}\right)$}

$\mathrm{O}_{2} \mathrm{P}$ was determined according to the ISO 15105-2:2003 Standard Test, following the methodology reported by Fernandes et al. (2018). Briefly, the films were sealed between two chambers, each one with two channels (for the input and output of fluxes). To keep a constant pressure, a controlled oxygen flow rate of $25 \mathrm{~mL} \mathrm{~min}^{-1}$ was supplied in the top chamber. Nitrogen was used as carrier gas, to purge the bottom chamber, at a controlled flux rate of $5 \mathrm{~mL} \mathrm{~min}^{-1}$. Then, $500 \mu \mathrm{L}$ of sample were collected from nitrogen flow, with a syringe for gas chromatography (Hamilton, Switzerland), and injected into a gas chromatograph (Bruker Scion 456, Canada), in order to measure the $\mathrm{O}_{2}$ concentration. A mixture of $\mathrm{CO}_{2}(10 \%), \mathrm{O}_{2}(20 \%)$, and $\mathrm{N}_{2}(70 \%)$, was used as standard for calibration. The assay was conducted in triplicate. The $\mathrm{O}_{2} \mathrm{P}$ was expressed as $\mathrm{g} \mathrm{m}^{-1} \mathrm{~s}^{-1} \mathrm{~Pa}^{-1}$, and determined by using the following equation (Cooksey et al., 1999):

$$
\mathrm{O}_{2} \mathrm{P}_{\mathrm{b}}=\frac{\mathrm{L}_{\mathrm{b}}}{\left(\frac{\mathrm{L}_{\mathrm{t}}}{\mathrm{O}_{2} \mathrm{P}_{\mathrm{t}}}\right)-\left(\frac{\mathrm{L}_{\mathrm{a}}}{\mathrm{O}_{2} \mathrm{P}_{\mathrm{a}}}\right)}
$$

where: $a$, is the A/C PET support; $b$, the nanolayers; and $t$, represents the resulting coated A/C PET support (A/C PET + five nanolayers); $\mathrm{L}$, is the thickness of the films (mm); and $\mathrm{O}_{2} \mathrm{P}$, corresponds to the oxygen permeability $\left(\mathrm{g} \mathrm{m}^{-1} \mathrm{~s}^{-1} \mathrm{~Pa}^{-1}\right)$.

\subsection{Tomato shelf-life analyses}

\subsubsection{Experimental design}

The experiment was carried out under controlled storage conditions in a chamber (Binder, USA) with temperature at $20^{\circ} \mathrm{C}$ and $\mathrm{RH}$ of $85 \%$, under a completely randomized design with three treatments: uncoated fruit (UCF) as control; nanolaminate coating (NL); and nanolaminate coating with $F$. cernua extract (NL $+\mathrm{FcE}$ ), with a variable number of repetitions for the evaluated parameters.

\subsubsection{Nanolaminate coatings application on tomato}

For each treatment, 39 fruit were used, with a total of 117 fruit for the three treatments, for the evaluation of the different variables. Before the application of the nanolaminate coatings, the surface of the tomatoes was cleaned with distilled water. Tomatoes samples were dipped into the coating solutions, during $10 \mathrm{~s}$ in each one (Olivas et al., 2007; Singh et al., 2010), with the following sequences: Alg-Chi-Alg-Chi-Alg, for the NL treatment; and Alg + FcE-Chi + $\mathrm{FcE}-\mathrm{Alg}+\mathrm{FcE}-\mathrm{Chi}+\mathrm{FcE}-\mathrm{Alg}+\mathrm{FcE}$, for the NL + FcE treatment. Between each solution application, the tomatoes samples were rinsed with distilled water at $\mathrm{pH} 7.0$ for the solutions containing $\mathrm{Alg}$ ( $\mathrm{Alg}$ or $\mathrm{Alg}+\mathrm{FcE}$ ), or $\mathrm{pH} 3.0$ for solutions containing Chi (Chi or Chi $+\mathrm{FcE}$ ); and left to dry at $30{ }^{\circ} \mathrm{C}$ for $20 \mathrm{~min}$ in a container with ventilation (Binder, USA).

\subsubsection{Physicochemical analyses of tomato}

2.7.3.1. Weight loss. Fifteen fruit were randomly selected, and separated into 3 groups or treatments (UCF, NL, NL + FcE), of 5 fruit each (each fruit was a replicate). Fruit were weighed using a precision balance (Mettler AE200, Germany) at the beginning of storage ( $0 \mathrm{~d}$ ) and at $3 \mathrm{~d}$ intervals for $15 \mathrm{~d}$. The weight loss was determined as follows:

Weight $\operatorname{loss}(\%)=\frac{\mathrm{W}_{\mathrm{i}}-\mathrm{W}_{\mathrm{f}}}{\mathrm{W}_{\mathrm{i}}} \times 100$

where $\mathrm{W}_{\mathrm{i}}$ is the fruit weight at $0 \mathrm{~d}$ and $\mathrm{W}_{\mathrm{f}}$ is the fruit weight at each sampling time.

2.7.3.2. $\mathrm{pH}$ and titratable acidity (TA). For the assays, three fruit per treatment were analyzed at regular intervals of $3 \mathrm{~d}$, during $15 \mathrm{~d}$. The samples were cut into small pieces and then, $50 \mathrm{~g}$ of each treatment were taken and ground in a blender. Subsequently, the mixtures were filtered under vacuum with a filter paper (Whatman No. 1). The $\mathrm{pH}$ of each treatment was determined using a potentiometer (Hanna Instruments Inc., Romania), by the direct immersion of the electrode. The TA was determined using $10 \mathrm{~mL}$ of pulp from each fruit, to which 2 drops of phenolphthalein (1\%) were added and titrated with $0.1 \mathrm{~N}$ $\mathrm{NaOH}$ (AOAC, 1990). Results were expressed in percent of citric acid (\% CA).

2.7.3.3. Color. . Tomato skin color values of five fruit (each fruit was a replicate), for each treatment, were measured in two times: at start (0 d), and end (15 d) of the assay; following the technique reported by Souza et al. (2009). Briefly, readings at three points on the circumference of the fruits were recorded using a Minolta colorimeter (CR 400; Minolta, Japan), calibrated with a white color plate $(Y=93.5$, $x=0.3114, y=0.3190$ ). The results were reported as redness values, according to the scale for tomato fruit proposed by Batu (2004) (Table 1), and calculated by the following equation:

Redness $=\frac{\mathrm{a}^{*}}{\mathrm{~b}^{*}}$

where $a^{*}$ represents the degree of redness, and $b^{*}$ represents yellowness, according to the chromaticity parameters given by the Minolta colorimeter.

2.7.3.4. Firmness. Tomato firmness was measured at the equatorial 
Table 1

Classification of color and mature stages of tomato fruit according to redness values (Batu, 2004).

\begin{tabular}{ll}
\hline Redness values $\left(\mathrm{a}^{*} / \mathrm{b}^{*}\right)$ & USDA tomato color stages \\
\hline-0.59 to -0.47 & Green \\
-0.47 to -0.27 & Breaker \\
-0.27 to 0.08 & Turning \\
0.08 to 0.60 & Pink \\
0.60 to 0.95 & Light-red \\
0.95 to 1.21 & Red \\
\hline
\end{tabular}

region of seven fruit per treatment (each fruit was a replicate), in two times: at start $(0 \mathrm{~d})$, and end $(15 \mathrm{~d})$ of the assay. A texture analyzer TAXT (Stable Micro System Ltd., UK) with a $5 \mathrm{~mm}$ stainless steel cylindrical flat head probe ( $\mathrm{P} / 5$ probe), was used. Briefly, the probe descended to the tomato with a pre-test speed of $1.50 \mathrm{~mm} \mathrm{~s}^{-1}$, a test speed of $5.00 \mathrm{~mm} \mathrm{~s}^{-1}$ and a post-test speed of $10.00 \mathrm{~mm} \mathrm{~s}^{-1}$, to determinate the force $(\mathrm{N})$ required to penetrate $20 \mathrm{~mm}$ in the fruit, measured at the break point. The break point was determined by autoforce trigger type, with a trigger force of $0.049 \mathrm{~N}$. The results were expressed in Newton $(\mathrm{N})$.

\subsubsection{Gas transference rate and ethylene production}

Measurements of gas transference $\left(\mathrm{O}_{2}\right.$ and $\left.\mathrm{CO}_{2}\right)$ and ethylene production of the treatments, were conducted by the closed system method, with two containers per treatment (UCF, NL, NL + FcE), each one containing one fruit. The technique reported by Cerqueira et al. (2009), with some modifications, was followed. Briefly, air was used as initial atmosphere, and $20 \mathrm{~mL}$ of saturated salt solution of potassium chloride $\left(\mathrm{RH}=85 \%\right.$ at $20^{\circ} \mathrm{C}$ ) were placed in a glass container of $2 \mathrm{~L}$, in order to achieve the desired RH. Subsequently, a whole fruit was placed inside the container, separated from the solution by means of a mesh. The containers were closed and placed in a chamber with controlled temperature and humidity $\left(20^{\circ} \mathrm{C}\right.$ and $\left.65 \% \mathrm{RH}\right)$, to maintain the storage conditions. The concentrations of $\mathrm{O}_{2}, \mathrm{CO}_{2}$ and ethylene inside the containers, were measured by taking gas samples by triplicate with a $500 \mu \mathrm{L}$ syringe, suitable for gas chromatography (Hamilton, Switzerland), through a silicone septum fitted in the container lid. The gas concentrations were measured daily during $15 \mathrm{~d}$.

The $\mathrm{O}_{2}$ and $\mathrm{CO}_{2}$ concentrations were determined by a gas chromatograph (Bruker Scion 456, Germany), equipped with a thermal conductivity detector (TCD) at $130^{\circ} \mathrm{C}$, and two columns. The $\mathrm{O}_{2}$ was determined with a column SS MolSieve $13 \times(80 / 100), 2 \mathrm{~m} \times 2$ $\mathrm{mm} \times 1 / 8^{\prime \prime}$, using argon as carrier gas at $60 \mathrm{~mL} \mathrm{~min}^{-1}$. The $\mathrm{CO}_{2}$ was determined using a Poraplot column with helium as carrier gas at $4 \mathrm{~mL}$ $\min ^{-1}$. For calibration, a mixture containing $10 \% \mathrm{CO}_{2}, 20 \% \mathrm{O}_{2}$, and $70 \% \mathrm{~N}_{2}$ was used as standard.

The ethylene content was determined using a gas chromatograph (Varian Star $3400 \mathrm{CX}$, USA), equipped with a flame ionization detector (FID) at $280^{\circ} \mathrm{C}$ and a non-polar column (Varian). Helium was used as carrier gas at $1 \mathrm{~mL} \mathrm{~min}{ }^{-1}$. A standard ethylene sample $\left(500 \mathrm{mg} \mathrm{L}^{-1}\right)$ was used for calibration.

The $\mathrm{O}_{2}$ consumption and $\mathrm{CO}_{2}$ and ethylene production rates, were calculated in accordance to the equations reported by Salvador et al. (2002), as follows:

$\mathrm{dy}_{\mathrm{O}_{2}}=-\mathrm{R}_{\mathrm{O}_{2}} \frac{\mathrm{W}_{\mathrm{t}}}{\mathrm{V}_{\mathrm{f}}} \mathrm{dt}$

$\mathrm{dy}_{\mathrm{CO}_{2}}=\mathrm{R}_{\mathrm{CO}_{2}} \frac{\mathrm{W}_{\mathrm{t}}}{\mathrm{V}_{\mathrm{f}}} \mathrm{dt}$

$\mathrm{dy}_{\text {ethylene }}=\mathrm{R}_{\text {ethylene }} \frac{\mathrm{W}_{\mathrm{t}}}{\mathrm{V}_{\mathrm{f}}} \mathrm{dt}$

Where $\mathrm{R}_{\mathrm{O}_{2}}$ represents the $\mathrm{O}_{2}$ consumption rate in $\mathrm{ng}\left[\mathrm{O}_{2}\right] \mathrm{kg}^{-1} \mathrm{~s}^{-1}$; $\mathrm{R}_{\mathrm{CO}_{2}}$ is the $\mathrm{CO}_{2}$ production rate in $\mathrm{ng}\left[\mathrm{CO}_{2}\right] \mathrm{kg}^{-1} \mathrm{~s}^{-1} ; \mathrm{R}_{\text {ethylene }}$ is the ethylene production rate in $\mathrm{ng}$ [ethylene] $\mathrm{kg}^{-1} \mathrm{~s}^{-1} ; \mathrm{W}_{\mathrm{t}}$ is the tomato weight $(\mathrm{kg})$; and $\mathrm{V}_{\mathrm{f}}$ is the free volume $(\mathrm{mL})$ of the container.

The free volume of the container was calculated as follows:

$\mathrm{V}_{\mathrm{f}}=\mathrm{V}_{\mathrm{P}}-\frac{\mathrm{W}}{\rho_{\text {tomato }}}$

where $\mathrm{V}_{\mathrm{P}}$ is the total volume of the container in milliliters $(\mathrm{mL}), \mathrm{W}$ is the tomato weight $(\mathrm{kg})$ and $\rho_{\text {tomato }}$, is the density of the tomato.

The graphs of $\mathrm{O}_{2}$ consumed and $\mathrm{CO}_{2}$ and ethylene produced against time, were used to calculate the slopes, which correspond to the derivative, dy/dt of each gas.

\subsubsection{Microbiological analyses}

Microbiological analyses were carried out by counting the total molds, yeasts, and aerobic mesophilic microorganisms in three fruit per treatment, every third day and during $15 \mathrm{~d}$, following the reported by Olivas et al. (2007). The sampled fruit were milled in a food processor. Then, $10 \mathrm{~g}$ of each sample were transferred to individual sterile stomacher bags (VWR Scientific, USA) containing $90 \mathrm{~mL}$ of sterilized $0.1 \%$ peptone water. The samples were homogenized for $120 \mathrm{~s}$ in a blender Stomacher 3500 (Seward Medical, London, U.K.). A total of five serial decimal dilutions (from $1 \times 10^{-1}$ to $1 \times 10^{-5}$ ) of the samples were prepared with peptone water, and then, $1 \mathrm{~mL}$ of each dilution was pourplated on Petri dishes. Subsequently, plate count agar (PCA) was added to the Petri dishes and the mixture was homogenized. Afterwards, the Petri dishes were left to solidification and incubated at $37^{\circ} \mathrm{C}$ for $48 \mathrm{~h}$, in order to count the aerobic mesophilic microorganisms. For the molds and yeasts, the same decimal dilutions were spread in Petri dishes containing DRBC agar and incubated at $25{ }^{\circ} \mathrm{C}$ for $5 \mathrm{~d}$. The assays were conducted with four replicates. The results were expressed as logarithm of colony forming units per gram ( $\left.\log \mathrm{CFU} \mathrm{g}^{-1}\right)$.

\subsection{Statistical analysis}

The statistical analyses were carried out using analysis of variance (ANOVA) and means comparison by Tukey test $(p<0.05)$ with the programs StatSoft, Inc. (2011) and STATISTICA v.10, while for the microbiological analyses, SAS-PC System v. 9.1.3 was used. In the gas transfer analyses, GraphPad Prism v.6.1 was used for linear regression analyses.

\section{Results and discussion}

\subsection{Characterization of the edible nanolaminate coatings on PET}

\subsection{1. $\zeta$-potential}

It was determined that the $\zeta$-potential value for pure Alg was $-75.77 \pm 1.10 \mathrm{mV}$ at $\mathrm{pH} 7.0$; while the addition of $F$. cernua extract to the $\mathrm{Alg}$ solution, increased its charge to $-42.50 \pm 1.42 \mathrm{mV}$ at $\mathrm{pH} 7.0$ (Table 2). On the other hand, the values of pure Chi and Chi + FcE showed charges of $52.03 \pm 2.61 \mathrm{mV}$ and $45.40 \pm 1.93 \mathrm{mV}$, respectively, at $\mathrm{pH}$ 3.0. These values confirm the opposite charges of each solution to the PET support, which allows its interaction with the Alg and $\mathrm{Alg}+\mathrm{FcE}$ solutions; and also, the interaction between the

Table 2

Zeta potential of polyelectrolyte solutions.

\begin{tabular}{ll}
\hline Solutions & Zeta Potential (mV) \\
\hline $\mathrm{Alg}$ & $-75.77 \pm 1.10 \mathrm{~b}$ \\
$\mathrm{Alg}+\mathrm{FcE}$ & $-42.50 \pm 1.42 \mathrm{a}$ \\
$\mathrm{Chi}$ & $52.03 \pm 2.61 \mathrm{a}$ \\
$\mathrm{Chi}+\mathrm{FcE}$ & $45.40 \pm 1.93 \mathrm{~b}$ \\
\hline
\end{tabular}

Alg: alginate; Chi: chitosan; FcE: F. cernua extract. Different letters into the same column indicate statistical difference $(p<0.05)$. 


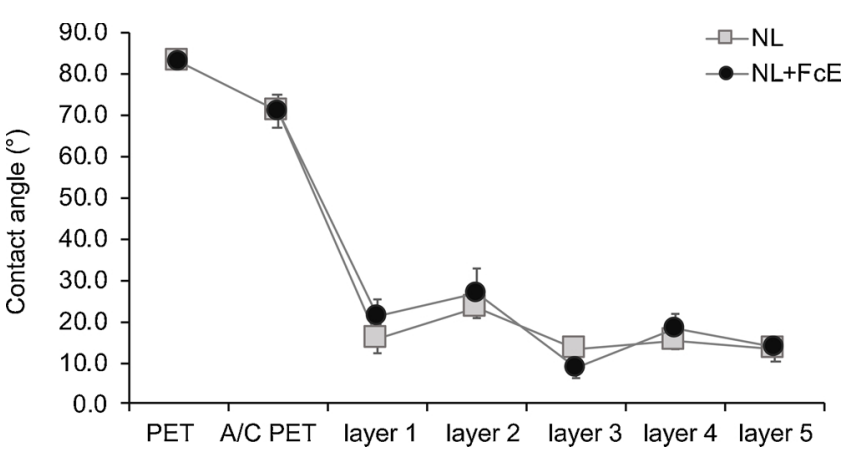

Fig. 1. Contact angle on original PET, A/C PET and the five successive layers of each nanolaminate coating. Error bars represent the standard deviation.

polyelectrolyte solutions (Alg and $\mathrm{Chi}$; $\mathrm{Alg}+\mathrm{FcE}$ and $\mathrm{Chi}+\mathrm{FcE}$ ) by electrostatic forces (Carneiro-da-Cunha et al., 2010).

\subsubsection{Contact angle}

It was observed that the contact angle of the original PET film $\left(82.93^{\circ}\right)$ was higher than the A/C PET $\left(71.15^{\circ}\right.$ ) (Fig. 1), however this tendency has been described by Carneiro-da-Cunha et al. (2010) and Pinheiro et al. (2012). These authors reported that the difference between the contact angles of A/C PET and original PET confirms that the aminolysis process was correctly conducted. On the other hand, a different behavior was observed when the nanolayers were assembled, varying the contact angle between Alg and Chi, with and without FcE, which confirms that the coating was sequentially assembled. It can be noted that the nanolayer containing Chi, has higher values than the nanolayer containing Alg. This difference between the values may be due to the fact that Chi is more hydrophobic than Alg (Medeiros et al., 2012a). The FcE incorporation did not influence in the nature of Alg and Chi. The contact angle differences found between the surfaces and nanolayers could be attributed to diverse factors, such as the chemical composition of the materials, level of interpenetration, and the swelling of the layers when they are in contact with water (Pinheiro et al., 2012).

\subsubsection{Water vapor and oxygen permeabilities}

WVP of the nanolaminates without A/C PET, showed values higher than the aminolyzed ones (Table 3). It can be noted that in the formulation of A/C PET with nanolaminates (NL, NL + FcE), the WVP values decreased. However, the addition of $F$. cernua extract to the nanolaminates did not have any influence in the WVP value and were not statistically different with the NL. The WVP is an essential consideration that the food industry takes into account for packaging (Souza et al., 2009). Therefore, this value should be low as the edible coatings must have the function to act as a retardant in the moisture transfer between the coated product and the environment (Gontard et al., 1992). The results obtained in this study, are similar to the reported by Pinheiro et al. (2012) and Medeiros et al. (2012b), who also obtained low values for the nanolaminate coatings. The decrease in the WVP observed in this study, could be attributed to the strong bonds that

Table 3

Water vapor (WVP) and oxygen $\left(\mathrm{O}_{2} \mathrm{P}\right)$ permeability of A/C PET, nanolayers, and aminolyzed nanolayers.

\begin{tabular}{lll}
\hline & WVP $\left(\mathrm{g} \mathrm{m}^{-1} \mathrm{~s}^{-1} \mathrm{~Pa}^{-1}\right) \times 10^{-}$ & $\mathrm{O}_{2} \mathrm{P}\left(\mathrm{g} \mathrm{m}^{-1} \mathrm{~s}^{-1} \mathrm{~Pa}^{-1}\right) \times 10^{-}$ \\
& & \\
\hline A/C PET & $11.90 \pm 0.87 \mathrm{a}$ & $0.72 \pm 0.19 \mathrm{a}$ \\
A/C PET-NL & $10.70 \pm 0.57 \mathrm{a}$ & $0.54 \pm 0.53 \mathrm{a}$ \\
A/C PET-NL + FcE & $10.80 \pm 0.22 \mathrm{a}$ & $0.45 \pm 0.37 \mathrm{a}$ \\
NL & $0.42 \pm 0.20 \mathrm{~b}$ & $0.002 \pm 0.001 \mathrm{~b}$ \\
NL + FcE & $0.42 \pm 0.08 \mathrm{~b}$ & $0.006 \pm 0.004 \mathrm{~b}$ \\
\hline
\end{tabular}

Different letters into the same column indicate statistical difference $(p<0.05)$.

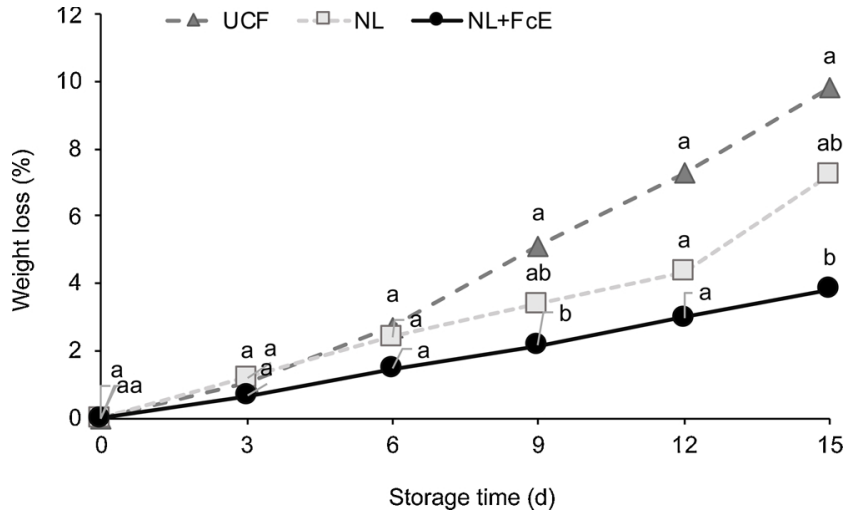

Fig. 2. Tomato fruit weight loss (\%) during storage time. Error bars represent the standard deviation.

are produced between the Alg and Chi layers (Jang et al., 2008), which avoid or decrease the water vapor diffusion.

On the other hand, the $\mathrm{O}_{2} \mathrm{P}$ values obtained for the A/C PET nanolaminate coatings, were higher than the nanolaminate coatings without PET (Table 3). However, the NL and NL + FcE were not statistical different. The above demonstrates that the nanolaminates are a notable barrier against the flow of $\mathrm{O}_{2}$.

These results in the WVP and $\mathrm{O}_{2} \mathrm{P}$ could be related to the existent interactions between the five nanolayers. Carneiro da-Cunha et al. (2010) cited that the decrease of the barrier properties in the nanolaminate coating is attributed to the increment of the tortuosity originated by the interactions between the nanolayers, which decrease the permeability of the nanolaminate coating.

\subsection{Effect of edible nanolaminate coatings on tomato shelf-life}

\subsubsection{Weight loss}

Results showed an increment of weight loss in all treatments, during the shelf-life assay (Fig. 2), observing that the highest weight loss occurred on day 15. It was noted that fruit treated with the $\mathrm{NL}+\mathrm{FcE}$, presented the lowest loss (3.8\%), while the highest loss was observed with the UCF (9.8\%). The incorporation of $F$. cernua into the nanolaminates delayed the weight loss of the fruit, when compared with the nanolaminates without the extract. This tendency in the weight loss during storage, is natural, as the loss occurs mainly by the transpiration process (Souza et al., 2014; Flores-López et al., 2016a; Mohanad et al., 2016). However, a loss higher than $5 \%$ is a restricting factor for the fruit marketing and consumption (Aktas et al., 2012). On the other hand, it has been reported that the nanolaminates act as a barrier in the weight loss (Medeiros et al., 2012b). Also, similar behaviors to the ones observed in this study have been reported by Vieira et al. (2016), who worked with blueberries coated with nanolaminates functionalized with Aloe vera. Besides, other studies in tomato fruit reported that the conventional coating with guar gum, had losses above $15 \%$ of the fruit weight (Ruelas-Chacon et al., 2017), values higher than the ones obtained in this study. These differences can be attributed to the enhanced barrier properties of the nanolaminate coatings, which due to the electrostatic interactions, between the Alg and Chi layers with the addition of $F$. cernua, decreased the diffusion of the water vapor molecules through the matrix of the materials (Souza et al., 2014). For the above, the addition of $F$. cernua to the nanolaminates is remarkable, as it avoids a high weight loss, and also the postharvest losses.

\subsection{2. $\mathrm{pH}$ and titratable acidity (TA)}

$\mathrm{pH}$ and TA of fruit from treatments varied over time (Table 4). The $\mathrm{pH}$ values of the NL and NL + FcE treatments increased with the storage time and were not statistical different, while for the UCF, the $\mathrm{pH}$ decreased. It has been reported that the $\mathrm{pH}$ of tomato fruit increases 
Table 4

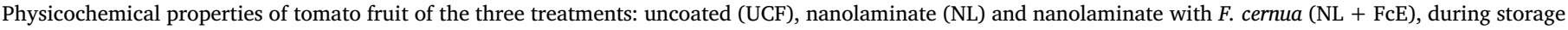
at $20^{\circ} \mathrm{C}$ and $85 \% \mathrm{RH}$.

\begin{tabular}{|c|c|c|c|c|c|c|c|}
\hline \multirow[b]{2}{*}{ Variable } & \multirow[b]{2}{*}{ Treatments } & \multicolumn{6}{|c|}{ Time (d) } \\
\hline & & 0 & 3 & 6 & 9 & 12 & 15 \\
\hline \multirow[t]{3}{*}{ pH } & UCF & $4.52^{\mathrm{Aa}}$ & $4.19^{\mathrm{Cc}}$ & $4.19^{\mathrm{Bc}}$ & $4.26^{\mathrm{Bb}}$ & $4.16^{\mathrm{Bc}}$ & $4.17^{\mathrm{Bc}}$ \\
\hline & NL & $4.18^{\mathrm{Cc}}$ & $4.35^{\mathrm{Aa}}$ & $4.27^{\mathrm{Ab}}$ & $4.37^{\mathrm{Aa}}$ & $4.26^{\mathrm{Ab}}$ & $4.38^{\mathrm{Aa}}$ \\
\hline & $\mathrm{NL}+\mathrm{FcE}$ & $4.26^{\mathrm{Bbc}}$ & $4.23^{\mathrm{Bc}}$ & $4.29^{\mathrm{Ab}}$ & $4.15^{\mathrm{Cd}}$ & $4.28^{\mathrm{Ab}}$ & $4.34^{\mathrm{Aa}}$ \\
\hline \multirow[t]{3}{*}{ TA } & UCF & $0.38^{\mathrm{Aa}}$ & $0.33^{\mathrm{Bd}}$ & $0.34^{\mathrm{ABcd}}$ & $0.35^{\mathrm{Bbcd}}$ & $0.36^{\mathrm{Abc}}$ & $0.37^{\text {Aab }}$ \\
\hline & NL & $0.34^{\mathrm{Bab}}$ & $0.30^{\mathrm{Cc}}$ & $0.34^{\mathrm{Bab}}$ & $0.30^{\mathrm{Cc}}$ & $0.33^{\mathrm{Bb}}$ & $0.35^{\mathrm{Ba}}$ \\
\hline & $\mathrm{NL}+\mathrm{FcE}$ & $0.39^{\mathrm{Ab}}$ & $0.38^{\mathrm{Abc}}$ & $0.36^{\text {Acd }}$ & $0.4^{\mathrm{Aa}}$ & $0.36^{\mathrm{Ad}}$ & $0.37^{\mathrm{Abcd}}$ \\
\hline
\end{tabular}

TA = Titratable acidity (\% CA).

Different lowercase letters into the same row and different uppercase letters into the same column, indicate statistical differences $(p<0.05)$.

with maturation and storage time (González-Céspedes et al., 2004); however, this value should be ranged between 4.17 and 4.59 (Cantwell, 2006), range in which the $\mathrm{pH}$ reported for this study was found. Also, these values are in accordance with the reported by Fernández-Ruiz et al. (2004), who determined for tomatoes of the same studied species, from different countries, a range from 4.16 to 4.92 for $\mathrm{pH}$.

On the other hand, the TA of all treatments slightly decreased from day 0 to day 15. These low variations in the TA values, throughout the days of the treatments, suggest that the ripening in the fruit could have been delayed (Medeiros et al., 2012b). Also, the TA values observed in this study agree with those reported by Cantwell (2004) for tomato, from 0.2 to $0.6 \%$.

The increase in $\mathrm{pH}$ was proportional to the decrease in TA, and it has been reported that this tendency implies the declining of acid concentrations, with maturity (Anthon et al., 2011). Thus, according to the results obtained, it is remarkable that the addition of $F$. cernua to the nanolaminate coating could delay the ripening stage of tomato fruit.

\subsubsection{Color}

Redness $\left(a * / b^{*}\right)$ increased slightly in all treatments, where the highest $(p<0.05)$ development of color was presented in the UCF (1.05) (Fig. 3). The most remarkable result was observed with the $\mathrm{NL}+\mathrm{FcE}$, which maintained the light-red stage throughout the $15 \mathrm{~d}$ of experiment, while the UCF and NL changed to the red stage since day 3. The $F$. cernua addition to the nanolaminate coating allows to preserve the light-red color of tomato fruit, which is an acceptable color for its marketing and commercialization (Batu, 2004). The application of this technology is important, as it allows to extend the shelf-life of tomato fruit during its marketing. To date, there are no reports about the redness evaluation in tomato treated with edible nanolaminate coatings, with added plant extracts. However, information of this parameter in tomato treated with traditional edible coatings has been reported (Ruelas-Chacon et al., 2017).

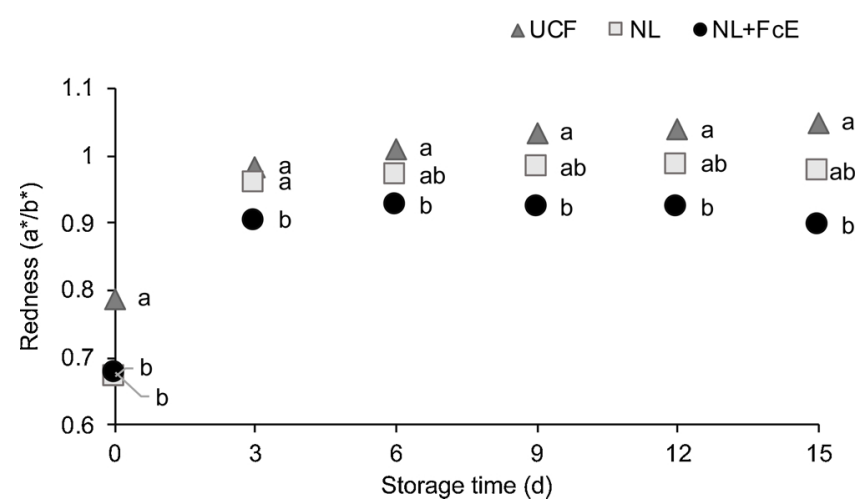

Fig. 3. Redness $\left(a^{*} / b^{*}\right)$ of tomato fruit stored for $15 \mathrm{~d}$ at $20^{\circ} \mathrm{C} / 85 \%$ RH. Error bars represent the standard deviation.

\subsubsection{Firmness}

The ripening process affects the texture of the fruit and the structure of the polysaccharide composition of the cell wall (Saladié et al., 2007). The softening changes have been associated with the degradation of the middle lamella of the cortical parenchyma cells, causing an increase in the pectin solubilization, but with minimal effects in its molecular weight and small changes in the hemicellulose content ( García et al., 2014).

For the fruit firmness, treatments were statistically different at the start of the experiment (Fig. 4), which could be attributed to the resin of F. cernua. Athmaselvi et al. (2013) reported this behavior with plant extracts, such as A. vera, which was used as base of nanolaminates to coat tomato fruit. At the end of this experiment, tomato firmness decreased in all treatments. Nevertheless, the NL + FcE treatment still showed the highest $(p<0.05)$ firmness $(3.8 \mathrm{~N})$, while the UCF and NL treatments were statistically equal and with the lowest firmness.

This tendency is in accordance with the reported by Zapata et al. (2007), who observed values of $11.65 \mathrm{~N}$ at harvest, which decreased to $4 \mathrm{~N}$ at the time of commercialization of the fruit. Softening of tomato fruit can be attributed to the enzymatic degradation of the cellular structure and cell wall components (Ali et al., 2010).

\subsubsection{Gas transference and ethylene production rates}

After $10 \mathrm{~d}$ of storage, the gas transference of $\mathrm{O}_{2}$ decrease for $\mathrm{NL}$ and $\mathrm{NL}+$ FcE treatments, when compared with the UCF (Fig. 5A). This indicates that the $\mathrm{O}_{2}$ consumed by the fruit, was reduced by the effect of the nanolaminates (NL and NL $+\mathrm{FcE}$ ), which were statistically equal. On the other hand, the $\mathrm{CO}_{2}$ transfer rate was lower for the $\mathrm{NL}$ and $\mathrm{NL}+$ FcE treatments, compared with the UCF, indicating that the respiration process was reduced due to the nanolaminate coatings. However, it has been reported that in fruit storage, the respiration rate depends directly of the $\mathrm{O}_{2}$ absorbed by the fruit (Fagundes et al., 2015). The above explains the results obtained in this study, as the low rate of

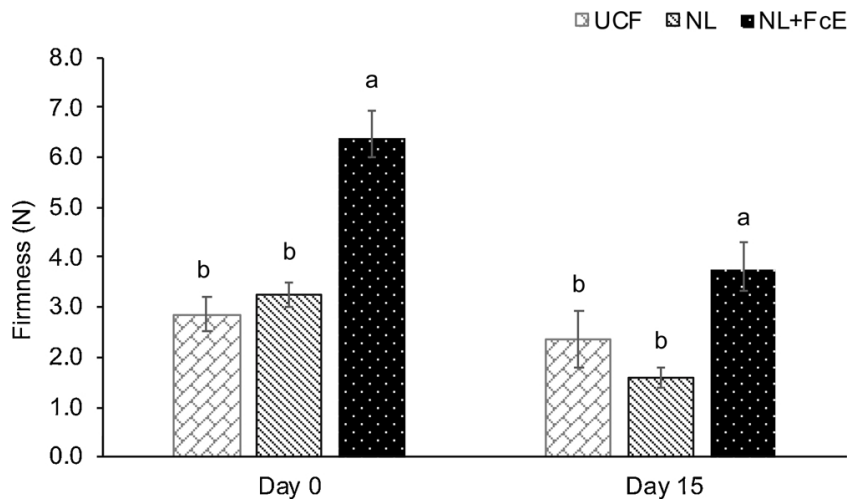

Fig. 4. Fruit firmness (N) of tomato fruit during storage at $20^{\circ} \mathrm{C} / 85 \% \mathrm{RH}$. Different letters into same day indicate statistical differences $(p<0.05)$. 
GCF $\square N L=N L+F c E$
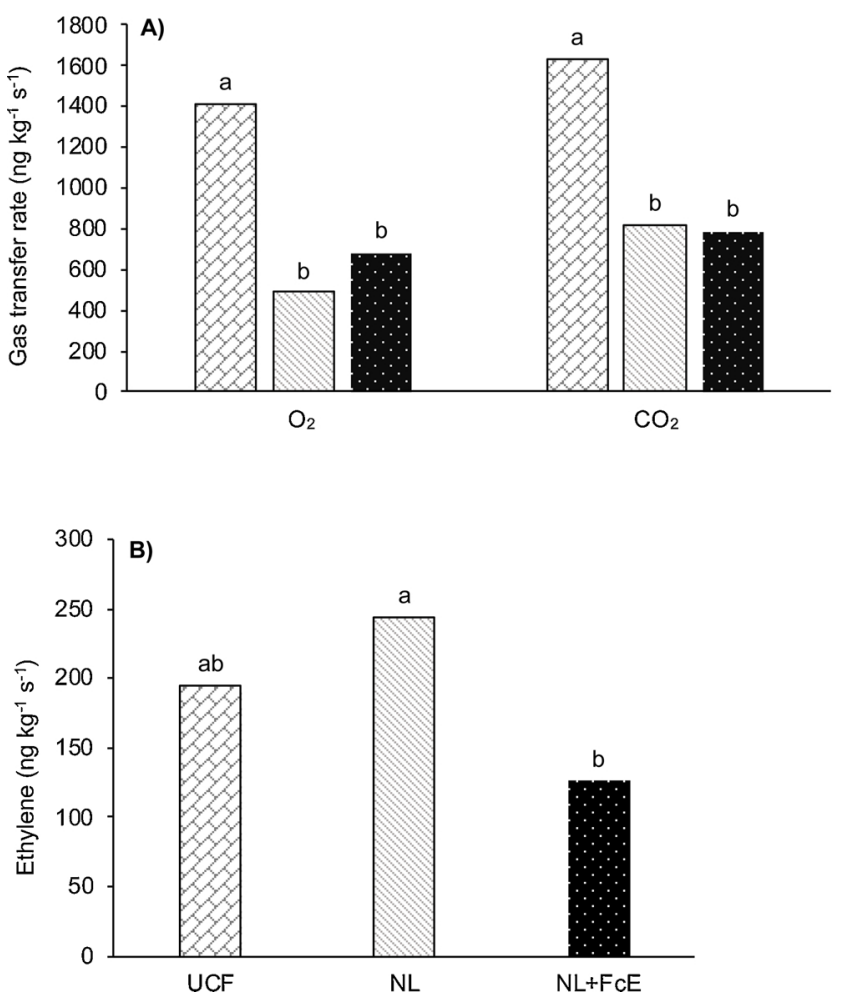

Fig. 5. Values of A) transfer rates of $\mathrm{O}_{2}$ and $\mathrm{CO}_{2}$, and $\mathrm{B}$ ) Ethylene production of tomato fruit uncoated and coated with NL and NL + FcE. Different letters for each gas indicate statistical differences $(p<0.05)$.

$\mathrm{O}_{2}$ absorbed by the fruit, influenced in a low rate of $\mathrm{CO}_{2}$ released. Ruelas-Chacon et al. (2017) reported a lower $\mathrm{CO}_{2}$ production of 'Roma' tomato fruit with guar gum traditional coating $\left(2.8 \mathrm{~mL} \mathrm{~kg}^{-1} \mathrm{~h}^{-1}\right)$, compared to uncoated tomatoes. Other authors have reported the reduction of the gas transference in tomato fruit, used during storage, coatings based on Arabic gum (Ali et al., 2010), and alginate or zein (Zapata et al., 2008).

For ethylene production, significant differences were detected between NL and NL + FcE treatments (Fig. 5B). Tomatoes treated with $\mathrm{NL}+\mathrm{FcE}$ had the lowest ethylene production $\left(126 \mathrm{ng} \mathrm{kg}^{-1} \mathrm{~s}^{-1}\right)$. Inhibition in the ethylene production is probably due to the reduced permeability of $\mathrm{O}_{2}$ and $\mathrm{CO}_{2}$, as it has been reported that low values of $\mathrm{O}_{2}$ reduce the synthesis of the ethylene, an important factor in fruit ripening (Fagundes et al., 2015). Also, in the biosynthetic pathway of ethylene, the enzyme ACC oxidase is the responsible of the ACC oxidation to ethylene, besides of its highly dependence to $\mathrm{O}_{2}$ and of its direct relation with $\mathrm{CO}_{2}$ and ethylene (Bolívar-Fernández et al., 2011).The above explains the relation that exists between the low rates of $\mathrm{O}_{2}, \mathrm{CO}_{2}$, and ethylene production, with the nanolaminate coatings in this study. Also, it has been reported that tomato fruit follow a pattern of climacteric ripening controlled by ethylene (Carrari and Fernie, 2006), which implies changes in the physical, chemical, biochemical and physiological processes. Therefore, the majority of storage technologies of postharvest are focused in the control of respiration and ethylene production, with the objective of delaying these changes (Martínez-Romero et al., 2007; Serrano et al., 2008). The reduction in the metabolic rates of the fruit due to coating applications on its surface, restricts the respiratory gas permeation. NL + FcE treatment showed a low gas transference rate, as a consumption decrease of $52 \%$ was observed on the $\mathrm{O}_{2}$ and $\mathrm{CO}_{2}$, when compared with the UCF. These results suggest that the $\mathrm{NL}+\mathrm{FcE}$ coating could give a barrier against the gas exchange and ethylene production between the internal and external environments.

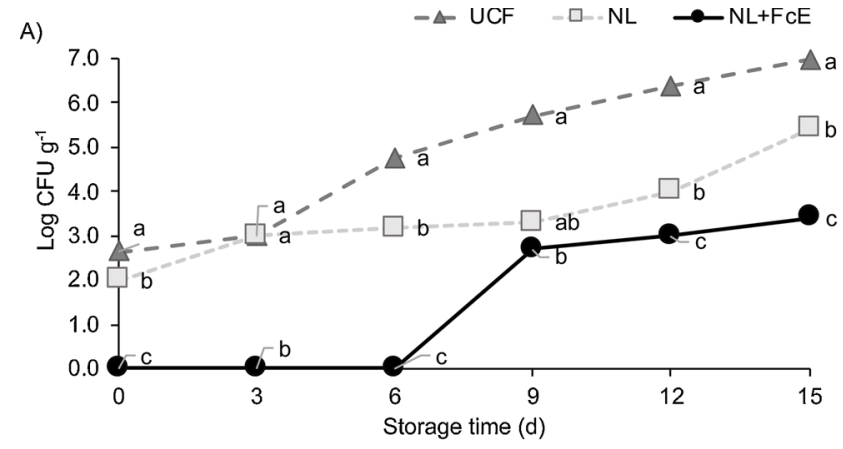

B)

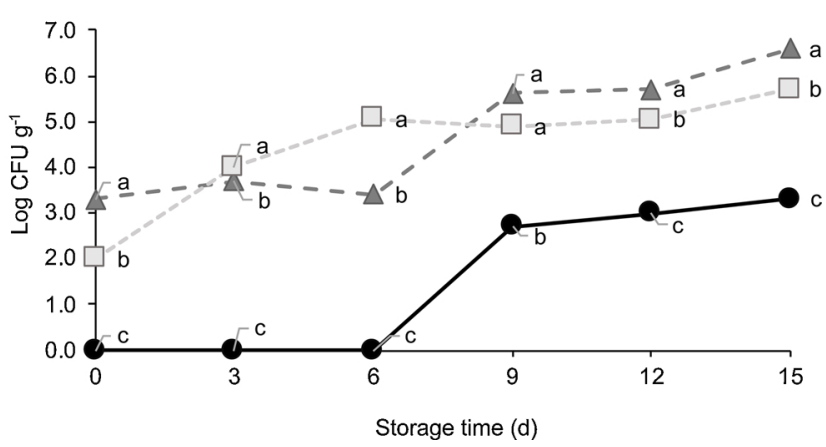

Fig. 6. Microbiological counting of A) molds and yeasts, and B) aerobic mesophilic microorganisms, throughout storage time of tomato fruit.

\subsubsection{Microbiological analyses}

The NL + FcE treatment resulted in the best control of the molds and yeasts (Fig. 6A), and aerobic mesophilic microorganisms (Fig. 6B). It is important to note that, with this treatment the fruit were not attacked by microorganisms during the first $6 \mathrm{~d}$ of storage. From day 9 to day 15 , the presence of microorganisms was observed, however, the $\mathrm{CFU} \mathrm{g^{-1 }}$ were low. This could be due to the combination of $F$. cernua extract with the other components of the nanolaminates, resulting in a better antimicrobial capacity. These results evidenced the antifungal activity of the ethanol extract of $F$. cernua, demonstrated in vitro (Jasso de Rodríguez et al., 2007, 2017), which was also observed on the fruit in this study. This effect could be promoted by the combination of the extract with chitosan, which has also reported antifungal activities (Rabea et al., 2003; Ai et al., 2012; Ruiz-Navajas et al., 2013). These results agree with those of Vieira et al. (2016), who worked with coatings of chitosan and A. vera liquid fraction and found lower levels in molds and yeasts ( $\mathrm{CFU} \mathrm{g} \mathrm{g}^{-1}$ ) in coated blueberry. Therefore, it is suggested that the addition of plant extracts to nanolaminate coatings, can improve its antimicrobial effect.

From the observed results in this study, it is assumed that the edible nanolaminate coating with $F$. cernua, continues releasing the active ingredient during storage, extending the shelf-life of the fruit.

\subsubsection{Visual evaluation}

The deterioration of tomatoes by molds, yeasts and aerobic mesophilic microorganisms causes metabolic alterations that are responsible for unpleasant smells and tastes, as well as of the visible changes in color and texture.

The tomato images with the three treatments (UCF, NL, and $\mathrm{NL}+\mathrm{FcE}$ ), evaluated during the $15 \mathrm{~d}$ of the experiment, are shown in Fig. 7. At 9 d, the UCF fruit softened, with proliferation of microorganisms on the fruit surface. Meanwhile, the NL treatment showed in the surface, the start of the presence of microorganisms, which continued increasing until day 15, although, the invasion is lower than in the UCF treatment. This effect could be attributed to the nanolaminate 


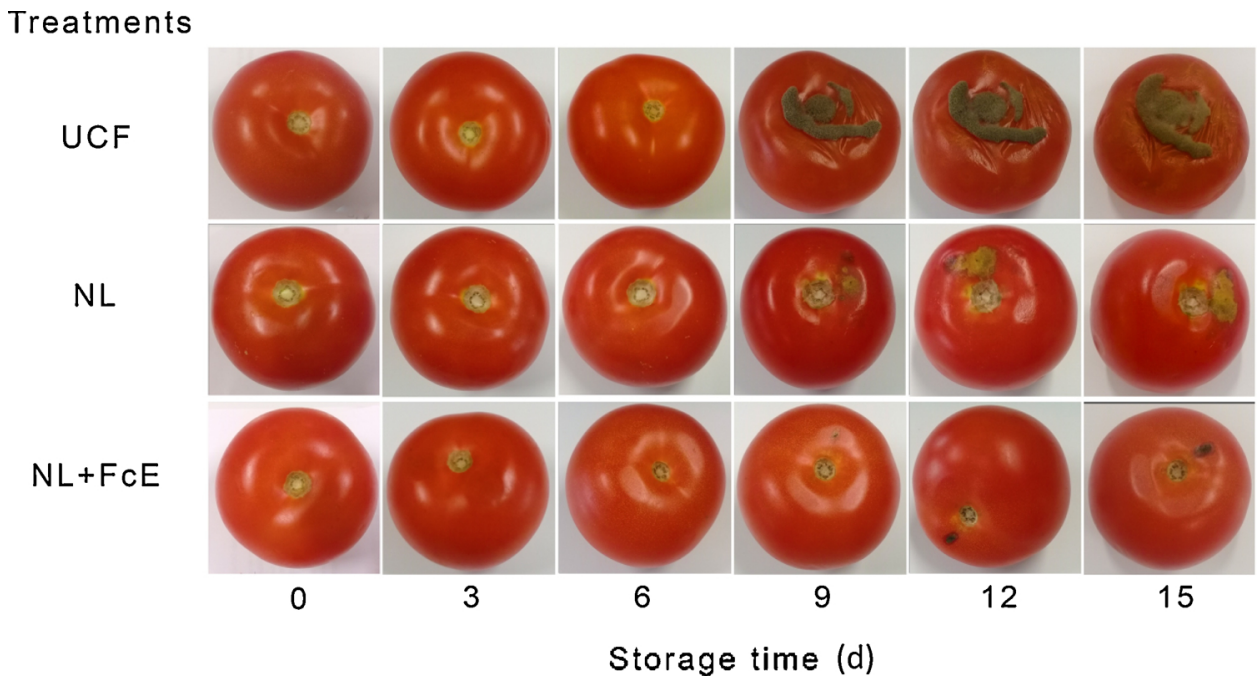

Fig. 7. Gradual change of tomato fruit throughout storage time at $20{ }^{\circ} \mathrm{C} / 85 \% \mathrm{RH}$.

coating of chitosan and alginate. In the case of the NL + FcE treatment, a healthy aspect was observed until day 12 . In day 15, a minimal presence of microorganisms on the tomato surface was observed. The positive effect of the nanolaminate coating with the $F$. cernua extract can inhibit the microorganisms. The antifungal effect of $F$. cernua has been reported in vitro (Jasso de Rodríguez et al., 2007, 2017), as well as for chitosan on green asparagus (Qiu et al., 2014).

As a final remark, authors wish to point out, that this is the first scientific research where $F$. cernua extract was added to nanolaminate coating, for the preservation of tomato fruit.

\section{Conclusions}

Edible nanolaminate coatings were developed using the layer-bylayer technique, which was demonstrated by the contact angle assay. The nanolaminate coatings containing $F$. cernua extract, had water vapor and $\mathrm{O}_{2}$ permeabilities lower than those reported for conventional coatings based on alginate or chitosan.

The nanolaminate coating containing $F$. cernua extract extended the shelf-life of tomato fruit at $20^{\circ} \mathrm{C}$ and $85 \% \mathrm{RH}$ for $15 \mathrm{~d}$. The coatings reduced weight loss, gas exchange rates of $\mathrm{O}_{2}$ and $\mathrm{CO}_{2}$, reduced ethylene production, which in turn delayed ripening, as indicated by firmness and light-red coloration of the fruit. The nanolaminate coating with $F$. cernua extract, was the most effective to inhibit the proliferation of molds, yeasts and aerobic mesophilic microorganisms in tomato fruit, and resulted in a healthy appearance until day 12 .

\section{Conflict of interest}

None.

\section{Funding}

This research did not receive any specific grant from funding agencies in the public, commercial, or not-for-profit sectors.

\section{Acknowledgments}

Author E. de J. Salas-Méndez thanks Mexican Science and Technology Council (CONACYT, Mexico) for PhD fellowship support. Authors want to thank PhD Zlatina Genisheva for the proof reading of the manuscript and suggestions to the same; also, to: María Guadalupe Moreno Esquivel, Edith E. Chaires Colunga, Olga L. Solís Hernández and M. Leticia Rodríguez González of the Phytochemistry Laboratory from Universidad Autónoma Agraria Antonio Narro, for their assistance in obtaining extracts and chemical composition.

\section{Appendix A. Supplementary data}

Supplementary material related to this article can be found, in the online version, at doi:https://doi.org/10.1016/j.postharvbio.2018.12. 008.

\section{References}

Ai, H., Wang, F., Xia, Y., Chen, X., Lei, C., 2012. Antioxidant, antifungal and antiviral activities of chitosan from the larvae of housefly, Musca domestica L. Food Chem. 132, 493-498. https://doi.org/10.1016/j.foodchem.2011.11.033.

Aktas, H., Bayindir, D., Dilmaçünal, T., Koyuncu, M.A., 2012. The effects of minerals, ascorbic acid, and salicylic acid on the bunch quality of tomatoes (Solanum lycopersicum) at high and low temperatures. Hortic. Scie. 47, 1478-1483.

Ali, A., Maqbool, M., Ramachandran, S., Alderson, P.G., 2010. Gum arabic as a novel edible coating for enhancing shelf-life and improving postharvest quality of tomato (Solanum lycopersicum L.) fruit. Postharvest Biol. Technol. 58, 42-47. https://doi.org/ 10.1016/j.postharvbio.2010.05.005.

Anthon, G.E., Lestrange, M., Barrett, D.M., 2011. Changes in pH, acids, sugars and other quality parameters during extended vine holding of ripe processing tomatoes. J. Sci. Food Agric. 91, 1175-1181. https://doi.org/10.1002/jsfa.4312.

AOAC, 1990. Official Methods of Analysis, 15th ed. Association of Official Analytical Chemists, Arlington, Virginia, USA.

Athmaselvi, K.A., Sumitha, P., Revathy, B., 2013. Development of Aloe vera based edible coating for tomato. Int. Agrophysics 27, 369-375. https://doi.org/10.2478/intag2013-0006.

Batu, A., 2004. Determination of acceptable firmness and colour values of tomatoes. J. Food Eng. 61, 471-475. https://doi.org/10.1016/S0260-8774(03)00141-9.

Bolívar-Fernández, N., Saucedo-Veloz, C., Sauri-Duch, E., 2011. Respiración y parámetros relacionados durante la maduración del chicozapote cosechado en la península de Yucatán. Rev. Bras. Fruct. E 261-266.

Cantwell, M., 2004. Fresh Market Tomato. Statewide Uniform Variety Trial Report Field and Postharvest Evaluations. Universidad de California, South San Joaquin Valley, USA.

Cantwell, M., 2006. Report to the California tomato Commission Tomato Variety Trials: Postharvest Evaluation for 2005. UCCE Fresh market tomato statewide report, California, USA.

Carneiro-da-Cunha, M.G., Cerqueira, M.A., Souza, B.W.S., Carvalho, S., Quintas, M.A.C., Teixeira, J.A., Vicente, A.A., 2010. Physical and thermal properties of a chitosan/ alginate nanolayered PET film. Carbohydr. Polym. 82, 153-159. https://doi.org/10. 1016/j.carbpol.2010.04.043.

Carrari, F., Fernie, A.R., 2006. Metabolic regulation underlying tomato fruit development. J. Exp. Bot. 57, 1883-1897. https://doi.org/10.1093/jxb/erj020.

Cerqueira, M.A., Lima, Á.M., Souza, B.W.S., Teixeira, J.A., Moreira, R.A., Vicente, A.A., 2009. Functional polysaccharides as edible coatings for cheese. J. Agric. Food Chem. 57, 1456-1462. https://doi.org/10.1021/jf802726d.

Cerqueira, M.A., Bourbon, A.I., Pinheiro, A.C., Martins, J.T., Souza, B.W.S., Teixeira, J.A., Vicente, A.A., 2011. Galactomannans use in the development of edible films/coatings for food applications. Trends Food Sci. Technol. 22, 662-671. https://doi.org/10. 1016/j.tifs.2011.07.002.

Cooksey, K., Marsh, K.S., Doar, L.H., 1999. Predicting permeability and transmission rate for multilayer materials. Food Technol. 53, 60-63. 
Fabra, M.J., Flores-López, M.L., Cerqueira, M.A., de Rodriguez, D.J., Lagaron, J.M., Vicente, A.A., 2016. Layer-by-Layer technique to developing functional nanolaminate films with antifungal activity. Food Bioprocess Technol. 9, 471-480. https://doi.org/ 10.1007/s11947-015-1646-1.

Fagundes, C., Moraes, K., Pérez-Gago, M.B., Palou, L., Maraschin, M., Monteiro, A.R. 2015. Effect of active modified atmosphere and cold storage on the postharvest quality of cherry tomatoes. Postharvest Biol. Technol. 109, 73-81. https://doi.org/ 10.1016/j.postharvbio.2015.05.017.

Fernandes, C., Calderon, V.S., Ballesteros, L.F., Cerqueira, M.A., Pastrana, L.M., Teixeira, J.A., Ferreira, P.J., Carvalho, S., 2018. Carbon-based sputtered coatings for enhanced chitosan-based films properties. Appl. Surf. Sci. 433, 689-695. https://doi.org/10. 1016/j.apsusc.2017.10.088.

Fernández-Ruiz, V., Sánchez-Mata, M.C., Cámara, M., Torija, M.E., Chaya, C., GalianaBalaguer, L., Roselló, S., Nuez, F., 2004. Internal quality characterization of fresh tomato fruits. Hortic. Sci. 39, 339-345.

Flores-López, M.L., Cerqueira, M.A., de Rodríguez, D.J., Vicente, A.A., 2016a. Perspectives on utilization of edible coatings and nano-laminate coatings for exten sion of postharvest storage of fruits and vegetables. Food Eng. Rev. 8, 292-305. https://doi.org/10.1007/s12393-015-9135-x.

Flores-López, M.L., Romaní, A., Cerqueira, M.A., Rodríguez-García, R., Jasso de Rodríguez, D., Vicente, A.A., 2016b. Compositional features and bioactive properties of whole fraction from Aloe vera processing. Ind. Crops Prod. 91, 179-185. https:// doi.org/10.1016/j.indcrop.2016.07.011.

Fu, J., Ji, J., Yuan, W., Shen, J., 2005. Construction of anti-adhesive and antibacterial multilayer films via layer-by-layer assembly of heparin and chitosan. Biomaterials 26 , 6684-6692. https://doi.org/10.1016/j.biomaterials.2005.04.034.

García, M., Casariego, A., Díaz, R., Roblejo, L., 2014. Effect of edible chitosan/zeolite coating on tomatoes quality during refrigerated storage. Emirates J. Food Agric. 26, 238-246. https://doi.org/10.9755/ejfa.v26i3.16620.

Gontard, N., Guilbert, S., Cuq, J.L., 1992. Edible wheat gluten films: influence of the main process variables on film properties using response surface methodology. J. Food Sci. 57, 190-195. https://doi.org/10.1111/j.1365-2621.1992.tb05453.x.

González-Céspedes, A., Salas-Sanjuán, M., del, C., Urrestarazu-Gavilán, M., 2004 Producción y calidad en el cultivo de tomate cherry. In: Urrestarazu-Gavilán, M. (Ed.), Tratado de Cultivos Sin Suelo. Mundi-Prensa, Madrid, pp. 703-704.

Hung, D.Van, Tong, S., Tanaka, F., Yasunaga, E., Hamanaka, D., Hiruma, N., Uchino, T., 2011. Controlling the weight loss of fresh produce during postharvest storage under a nano-size mist environment. J. Food Eng. 106, 325-330. https://doi.org/10.1016/j. jfoodeng.2011.05.027.

Jang, W.S., Rawson, I., Grunlan, J.C., 2008. Layer-by-layer assembly of thin film oxygen barrier. Thin Solid Films 516, 4819-4825. https://doi.org/10.1016/j.tsf.2007.08 141.

Jasso de Rodríguez, D., Hernández-Castillo, D., Angulo-Sánchez, J.L., Rodríguez-García, R., Villarreal Quintanilla, J.A., Lira-Saldivar, R.H., 2007. Antifungal activity in vitro of Flourensiaspp. extracts on Alternaria sp.,Rhizoctonia solani, and Fusarium oxysporum. Ind. Crops Prod. 25, 111-116. https://doi.org/10.1016/j.indcrop.2006.08. 007.

Jasso de Rodríguez, D., Salas-Méndez, E., de, J., Rodríguez-García, R., HernándezCastillo, F.D., Díaz-Jiménez, M.L.V., Sáenz-Galindo, A., González-Morales, S., FloresLópez, M.L., Villarreal-Quintanilla, J.A., Peña-Ramos, F.M., Carrillo-Lomelí, D.A., 2017. Antifungal activity in vitroof ethanol and aqueous extracts of leaves and branches ofFlourensia spp. against postharvest fungi. Ind. Crops Prod. 107, 499-508. https://doi.org/10.1016/j.indcrop.2017.04.054

Kwok, D.Y., Neumann, A.W., 1999. Contact angle measurement and contact angle interpretation. Adv. Colloid Interface Sci. https://doi.org/10.1016/S0001-8686(98) 00087-6.

Liplap, P., Vigneault, C., Toivonen, P., Charles, M.T., Raghavan, G.S.V., 2013. Effect of hyperbaric pressure and temperature on respiration rates and quality attributes of tomato. Postharvest Biol. Technol. 86, 240-248. https://doi.org/10.1016/j. postharvbio.2013.07.002.

Martínez-Romero, D., Serrano, M., Guillén, F., Castillo, S., Valero, D., 2007. Tools to maintain postharvest fruit and vegetable quality through the inhibition of ethylen action: a review. Crit. Rev. Food Sci. Nutr. 47, 543-560. https://doi.org/10.1080/ 10408390600846390.

Medeiros, B.G., de, S., Pinheiro, A.C., Carneiro-Da-Cunha, M.G., Vicente, A.A., 2012a. Development and characterization of a nanomultilayer coating of pectin and chitosan - Evaluation of its gas barrier properties and application on "Tommy Atkins" mangoes. J. FoodEng. 110, 457-464. https://doi.org/10.1016/j.jfoodeng.2011.12.021.

Medeiros, B.G., de, S., Pinheiro, A.C., Teixeira, J.A., Vicente, A.A., Carneiro-da-Cunha, M.G., 2012b. Polysaccharide/Protein nanomultilayer coatings: construction, characterization and evaluation of their effect on 'Rocha' pear (Pyrus communis L.) shelflife. Food Bioprocess Technol. 5, 2435-2445. https://doi.org/10.1007/s11947-010 0508-0.

Medeiros, B.Gd.S., Souza, M.P., Pinheiro, A.C., Bourbon, A.I., Cerqueira, M.A., Vicente, A.A., Carneiro-da-Cunha, M.G., 2014. Physical Characterization of an Alginate/
Lysozyme Nano-Laminate coating and its evaluation on "Coalho" cheese shelf life. Food Bioprocess Technol. 7, 1088-1098. https://doi.org/10.1007/s11947-0131097-5.

Mohanad, J.K., Azhar, A.S., Imad, H.H., 2016. Evaluation of anti-bacterial activity and bioactive chemical analysis of Ocimum basilicum using Fourier transform infrared (FTIR) and gas chromatography-mass spectrometry (GC-MS) techniques. J. Pharmacogn. Phyther. 8, 127-146. https://doi.org/10.5897/JPP2015.0366.

Olivas, G.I., Mattinson, D.S., Barbosa-Cánovas, G.V., 2007. Alginate coatings for preservation of minimally processed "Gala" apples. Postharvest Biol. Technol. 45, 89-96. https://doi.org/10.1016/j.postharvbio.2006.11.018.

Pinheiro, A.C., Bourbon, A.I., Medeiros, B.G.D.S., Da Silva, L.H.M., Da Silva, M.C.H., Carneiro-Da-Cunha, M.G., Coimbra, M.A., Vicente, A.A., 2012. Interactions between $\kappa$-carrageenan and chitosan in nanolayered coatings-structural and transport properties. Carbohydr. Polym. 87, 1081-1090. https://doi.org/10.1016/j.carbpol.2011. 08.040 .

Qiu, M., Wu, C., Ren, G., Liang, X., Wang, X., Huang, J., 2014. Effect of chitosan and its derivatives as antifungal and preservative agents on postharvest green asparagus. Food Chem. 155, 105-111. https://doi.org/10.1016/j.foodchem.2014.01.026.

Rabea, E.I., Badawy, E.T., Stevens, C.V., Smagghe, G., Steurbaut, W., 2003. Chitosan as antimicrobial agent: applications and mode of action. Biomacromolecules 4 , 1457-1465. https://doi.org/10.1021/bm034130m.

Ramos-García, M., Bosquez-Molina, E., Hernández-Romano, J., Zavala-Padilla, G., TerrésRojas, E., Alia-Tejacal, I., Barrera-Necha, L., Hernández-López, M., Bautista-Baños, S., 2012. Use of chitosan-based edible coatings in combination with other natural compounds, to control Rhizopus stolonifer and Escherichia coli DH5 $\alpha$ in fresh tomatoes. Crop Prot. 38, 1-6. https://doi.org/10.1016/j.cropro.2012.02.016.

Ruelas-Chacon, X., Contreras-Esquivel, J.C., Montañez, J., Aguilera-Carbo, A.F., ReyesVega, M.L., Peralta-Rodriguez, R.D., Sanchéz-Brambila, G., 2017. Guar gum as an edible coating for enhancing shelf-life and improving postharvest quality of Roma tomato (Solanum lycopersicum L.). J. Food Qual. 2017. https://doi.org/10.1155/ $2017 / 8608304$.

Ruiz-Navajas, Y., Viuda-Martos, M., Sendra, E., Perez-Alvarez, J.A., Fernández-López, J., 2013. In vitro antibacterial and antioxidant properties of chitosan edible films incorporated with Thymus moroderi or Thymus piperella essential oils. Food Control 30 386-392. https://doi.org/10.1016/j.foodcont.2012.07.052.

Saladié, M., Matas, A.J., Isaacson, T., Jenks, M.A., Goodwin, S.M., Niklas, K.J., Xiaolin, R., Labavitch, J.M., Shackel, K.A., Fernie, A.R., Lytovchenko, A., O'Neill, M.A., Watkins, C.B., Rose, J.K.C., 2007. A re-evaluation of the key factors that influence tomato fruit softening and integrity. Plant Physiol. 144, 1012-1028. https://doi.org/10.1104/pp. 107.097477.

Salvador, M.L., Jaime, P., Oria, R., 2002. Modeling of O2 and CO2 exchange dynamics in modified atmosphere packaging of Burlat cherries. J. Food Sci. 67, 231-235. https:// doi.org/10.1111/j.1365-2621.2002.tb11389.x.

Serrano, M., Zapata, P.J., Guillén, F., Martínez-Romero, D., Castillo, S., Valero, D., 2008. Post-harvest ripening of tomato. In: Preedy, V.R., Watson, R.R. (Eds.), Tomatoes and Tomato Products. Oxford \& IBH publishing, New Delhi, India, pp. 67-84.

Silva, H.D., Cerqueira, M.A., Vicente, A.A., 2015. Influence of surfactant and processing conditions in the stability of oil-in-water nanoemulsions. J. Food Eng. 167, 89-98. https://doi.org/10.1016/j.jfoodeng.2015.07.037.

Singh, C., Sharma, H.K., Sarkar, B.C., 2010. Influence of process conditions on the mass transfer during osmotic dehydration of coated pineapple samples. J. Food Process. Preserv. 34, 700-714. https://doi.org/10.1111/j.1745-4549.2009.00386.x.

Souza, B.W.S., Cerqueira, M.A., Casariego, A., Lima, A.M.P., Teixeira, J.A., Vicente, A.A., 2009. Effect of moderate electric fields in the permeation properties of chitosan coatings. Food Hydrocoll. 23, 2110-2115. https://doi.org/10.1016/j.foodhyd.2009. 03.021 .

Souza, M.P., Vaz, A.F.M., Cerqueira, M.A., Texeira, J.A., Vicente, A.A., Carneiro-daCunha, M.G., 2014. Effect of an edible nanomultilayer coating by electrostatic selfassembly on the shelf life of fresh-cut mangoes. Food Bioprocess Technol. 8, 647-654. https://doi.org/10.1007/s11947-014-1436-1.

Valero, D., Díaz-Mula, H.M., Zapata, P.J., Guillén, F., Martínez-Romero, D., Castillo, S., Serrano, M., 2013. Effects of alginate edible coating on preserving fruit quality in four plum cultivars during postharvest storage. Postharvest Biol. Technol. 77, 1-6. https://doi.org/10.1016/j.postharvbio.2012.10.011.

Vieira, J.M., Flores-López, M.L., de Rodríguez, D.J., Sousa, M.C., Vicente, A.A., Martins, J.T., 2016. Effect of chitosan-Aloe vera coating on postharvest quality of blueberry (Vaccinium corymbosum) fruit. Postharvest Biol. Technol. 116, 88-97. https://doi. org/10.1016/j.postharvbio.2016.01.011.

Zapata, L., Gerard, L., Davies, C., Oliva, L., Schvab, M., 2007. Correlación matemática de índices de color del tomate con parámetros texturales y concentración de carotenoides. Ciencia, Docencia y Tecnol. 34, 207-226.

Zapata, P.J., Guillén, F., Martínez-Romero, D., Castillo, S., Valero, D., Serrano, M., 2008. Use of alginate or zein as edible coatings to delay postharvest ripening process and to maintain tomato (Solanum lycopersicon Mill) quality. J. Sci. Food Agric. 88, 1287-1293. https://doi.org/10.1002/jsfa.3220. 